\title{
KIR2DL1 Gene
}

National Cancer Institute

\section{Source}

National Cancer Institute. KIR2DL1 Gene. NCI Thesaurus. Code C129016.

This gene is involved in the regulation of natural killer cell activity. 